\title{
Pendekatan Konseling Spiritual dalam Penyembuhan Pasien Narkoba di Inabah VII Tasikmalaya
}

\author{
Hajir Tajiri \\ ${ }^{2}$ Fakultas Dakwah dan Komunikasi, UIN Sunan Gunung Djati, Bandung \\ manghajir@gmail.com
}

\begin{abstract}
Healing of drug patients generally uses medical / therapeutic practices that are comprehensive on the physical, psychological and spiritual goals of the patient. The spiritual counseling approach is part of the healing practice with the aim of focusing psychologically and spiritually, yet many researchers have investigated, among others, how methods, counseling processes are conducted so that patients who get them are helped by the healing process. To prove the truth of the thesis, a descriptive method was used in a qualitative approach. The results show, healing patients in the spiritual counseling approach uses Islamic moral psychotherapy methods with the stage of awareness of the patient about the nature of the problem experienced, as a step in the assessment stage and awareness of the importance of healing and the mechanism carried out in healing as the handling stage. With the approach of spiritual counseling the effect that occurs in patients in the form of some self-improvement. Patients in inabah VII experienced better recovery. In addition to patients stopping drug addiction, patients also have improved mindset and actions, rearranged their mindsets and changed their way of life. Besides that, calm and confidence in the patient appears, and the most proud of those changes are in line with the guidance of Islamic spiritual teachings. Patients also have the readiness to live a better life in accordance with the provisions of religious teachings. Based on the results it can be concluded that the spiritual gcounseling approach can help patients to heal their condition.
\end{abstract}

Keywords: Spiritual Guidance, Narcotics, Patients

\section{ABSTRAK}

Penyembuhan pasien narkoba umumnya menggunakan praktek pengobatan/terapi yang komprehensif pada sasaran fisik, psikhis dan ruhani pasien. Pendekatan konseling spiritual merupakan bagian dari praktek penyembuhan dengan sasaran berfokus psikhis dan ruhani, belum banyak ditela'ah peneliti antara lain bagaimana metode, proses dan tahapan serta komunikasi konseling yang dilakukan sehingga pasien yang mendapatkannya terbantu proses kesembuhannya. Untuk membuktikan kebenaran tesis tersebut dilakukan penelitian dengan metode deskriptif dalam pendekatan kualitatif. Hasilnya menunjukkan, penyembuhan pasien dalam pendekatan konseling 
spiritual dengan tahapan penyadaran pasien tentang hakikat masalah yang dialami, sebagai langkah tahapan assesmen dan penyadaran arti penting penyembuhan dan mekanisme yang dijalankan dalam penyembuhan sebagai tahapan penanganan. Dengan pendekatan konseling spiritual efek yang terjadi pada pasien berupa beberapa perbaikan diri. Pasien di inabah VII mengalami kesembuhan lebih sempurna. Selain pasien berhenti dari adiksi narkoba, pasien juga memiliki perbaikan pola pikir dan tindakan, tertata ulang pola pikirnya serta berubah cara hidupnya. Selain itu muncul ketenangan dan keyakinan pada diri pasien, dan yang paling membanggakan perubahan itu sejalan dengan tuntunan ajaran spiritual Islam. Pasien pun memiliki kesiapan untuk menjalani hidup secara lebih baik sesuai dengan ketentuan ajaran agama. Berdasarkan hasil dapat disimpulkan pendekatan konseling spiritual dapat membantu pasien dalam menyembuhkan keadaan dirinya.

Kata Kunci: Konseling Spiritual, Narkoba, Pasien

\section{PENDAHULUAN}

Penyalahgunaan nafza merupakan penyakit sosial yang penangannya sulit dilakukan hingga tuntas. Korban dan atau pelakunya senantiasa ada dan bahkan terus bertambah. Presiden RI, Joko Widodo pernah menyebutkan jumlah pengonsumsi nafza saat ini mencampai jutaan orang. Kendati telah dibuat hukuman seberat-beratnya bahkan hukuman mati bagi pengedar narkoba, ternyata jumlah pengedar dan pemakai terus bertambah.

Menurut Deputi Bidang Pencegahan Badan Narkotika Nasional (BNN) Ali Djohardi, tingkat penyalahgunaan narkoba di Indonesia masih tinggi. Pengguna narkoba di Indonesia tercatat sebanyak 5,1 juta jiwa. Pengguna narkoba paling banyak itu berada di usia produktif 24-30 tahun. Setiap tahun, sekitar 15 ribu jiwa melayang karena menggunakan narkoba. Suatu jumlah yang spektakuler, padahal bahayanya menunjukkan telah memakan banyak korban. (News.Detik.com, 18 Pebruari 2017).

Ilustrasi tentang bahaya penyalahgunaan narkoba sebagaimana dikemukakan Fiddy Anggriawan (2015), pada Januari 2012 di kawasan Tugu Tani, Jakarta Pusat, sebuah mobil Daihatsu Xenia warna hitam bernomor polisi B 2479 XI, dikemudikan Afriyani Susanti melaju kencang dan tak terkendali hingga mengalami kecelakaan maut di depan halte Kementerian Perdagangan. Sembilan orang tewas. Publik pun tersentak karena Afriyani bersama tiga penumpang Xenia maut tersebut positif mengkonsumsi narkoba jenis ekstasi dan dalam pengaruh alkohol. Demikian juga seorang pengemudi sexy, Novi Amelia yang menggunakan mobil Honda Jazz bernomor polisi B 1864 POP menabrak tujuh orang di Jalan Gajah Mada, Tamansari, Jakarta Barat, pada Kamis 11 Oktober 2012. Pengemudi Honda Jazz tersebut pun diketahui mengkonsumsi 
narkoba jenis ekstasi. Pada awal 2015, kasus kecelakaan maut kembali terjadi. Christopher Daniel Sjarif, pengemudi Mitsubishi Outlander B 1658 PJE menabrak sembilan kendaraan di Jalan Iskandar Muda, Kebayoran Lama, Jakarta Selatan. Berdasarkan tes laboratorium Badan Narkotika Nasional (BNN), pemuda yang sedang menempuh pendidikan di Amerika Serikat ini terbukti menggunakan narkoba jenis LSD (Lycergic Syntetic Diethylamide).

Selain berbahaya dalam berkendaraan, juga dalam perspektif kesehatan konsumsi narkoba sangat berbahaya terhadap system syaraf otak. Sebagaimana dijelaskan oleh Sugiana, (2016), penggunaan obat-obatan (valium, kokain, morfin, heroin, ganja, ekstasi, dan sabu-sabu) memiliki pengaruh terhadap kerja sistem saraf, misalnya hilangnya koordinasi tubuh, karena di dalam tubuh pemakai kekurangan dopamin. Dopamin merupakan neurotransmitter yang terdapat di otak dan berperan penting dalam merambatkan impuls saraf ke sel saraf lainnya. Hal ini menyebabkan dopamin tidak dihasilkan. Apabila impuls saraf sampai pada bongkol sinapsis, maka gelembung-gelembung sinapsis akan mendekati membran presinapsis. Selain itu hilangnya kendali otot gerak, denyut jantung melemah, hilangnya nafsu makan, terjadi kerusakan hati dan lambung, kerusakan alat respirasi, gemetar terus-menerus, terjadi kram perut dan bahkan mengakibatkan kematian (Sugiana, 2016).

Kondisi di atas menyadarkan semua pihak yang bertekad menyelamatkan generasi terutama melalui serangkaian upaya penanganan baik preventif maupun penyembuhan (kuratif) bagi mereka yang sudah terindikasi menyalahgunakan nafza. Upaya mengatasi problem penyalah gunaan narkoba antara lain dilakukan oleh pesantren Inabah VII Sukahening Tasikmalaya. Menurut Aqib (2005: 158), pendekatan pesantren telah berhasil memulihkan tidak kurang dari ribuan korban. Pada kurun waktu 1989 - 1993 sekitar 1720 orang korban penyalahgunaan nafza di tangani di pesantren Suryalaya, $80 \%$ berhasil disembuhkan.

Fenomena banyaknya pasien yang dikirim ke pesantren/inabah dan fakta kesembuhan pasien narkoba yang ditangani oleh Pesantren, mengindikasikan bahwa pesantren telah mampu membuktikan kepada khalayak bahwa pesantren mampu menangani korban penyalahgunaan narkoba.

Beberapa penelitian telah membuktikan kebenarannya. Peneliti Haryanto (1999) menyebutkan, penyalahgunaan narkoba dapat disembuhkan dengan terapi religius di Pesantren Suryalaya. Terapi ini disebut terapi non-medis, mengandalkan ritual ibadah Islam seperti dzikir, shalat, talqin dan puasa. Zikir (eling) yang dimaksud adalah ingat hati kepada Allah. Zikir jahar adalah zikir yang diucapkan dengan suara keras dan dengan gerakan-gerakan serta ritme tertentu. shalat dikerjakan dengan jadwal yang sangat ketat dan tidak hanya shalat fardlu saja tetapi hampir semua shalat sunah. mandi dikenal dengan "mandi 
taubat" dilaksanakan pada puku 02.00/03.00 dini hari sewaktu akan menjalankan shalat tahajud.

Maesaroh (2009)pendekatan spiritual dalam konseling yaitu pengembangan hikmah ibadah (wudu, shalat, syukur, shabar, dzikir, do’a, membaca Al-Qur'an, dan menjalankan sunnah-sunnah rasul) cukup berpengaruh terhadap perubahan bio-psiko-sosio-spiritual pasien antara lain adanya semangat perbaikan diri pada pecandu, bersikap lebih shabar dan santun, lebih rileks dalam menanggapi permasalahan, sikap optimism terhadap masa depan, lebih mampu mengendalikan pikiran-pikiran negatif, berperilaku sesuai aqidah Islam, menegakkan nilai-nilai keimanan, melaksanakan ibadah wajib dan sunat, mewujudkan akhlak mulia, memaknai nilai aktivitas sebagai ibadah.

Berdasarkan sejumlah penelitian yang telah dilakukan para peneliti, tampaknya masih ada celah untuk dilakukan pendalaman lebih jauh yaitu berkait dengan posisi lembaga ini yang merupakan pesantren. Dalam pengamatan peneliti aktivitas pesantren ini tidak cukup jika hanya dikonotasikan dengan lembaga terapi, tetapi juga harus ada dimensi pencerahannya. Pesantren Suryalaya sesuai dengan nama lembaga ini pesantren tentu memiliki fungsi untuk memperbaiki perilaku buruk menjadi baik, mengembangkan pemahaman dan pengamalan arti hidup yang lebih bermakna sesuai ajaran Islam maupun meningkatkan kemampuan menjadi insan yang bertaqwa, beriman dan beramal shaleh. Pesantren ini sejak berdiri hingga sekarang terus melaksanakan fungsi tersebut guna memberikan manfaat bagi kehidupan manusia.

Pesantren Suryalaya seharusnya tidak hanya sekedar berfungsi untuk membantu penyembuhan atau pemulihan dalam arti berhenti dari kebiasaan mengonsumsi narkoba, tetapi sesuai karakteristik lembaga pesantren juga mampu membangun pemahaman diri (self-understanding) tentang siapa diri, apa yang harus dilakukan dan dijalani dalam menjalani kehidupan ini. Hal ini berarti pesantren menggunakan pendekatan konseling yaitu pendekatan yang menekankan perbaikan pola pikir dan kebiasaan serta terbangunnya kesadaran. Pendekatan konseling memiliki asumsi bahwa problem perilaku bersumber pada pikiran-pikiran yang salah, keyakinan yang keliru, yang kemudian berpengaruh terhadap sikap, cara merasa, cara berpikir dan berperilaku (Spiegler \& Guevremont, 2003: 310).

Karakteristik lainnya dari pendekatan konseling terletak pada tahapannya dimulai dengan tahap identifikasi masalah, pengenalan terhadap inti masalah), tahap penentuan teknik konseling yang relevan, dan tahap penerapan teknik dalam membantu konseli keluar dari masalah (Curwen, Palmer \& Ruddel, 2008: 20). Secara lebih operasional karakteristik tahapan ini juga dapat dijelaskan sebagai tahapan penerapan teknik konseling disesuaikan dengan kebutuhan dan level beratnya masalah, antara lain konseli diajak untuk mengenal lebih jauhinti masalah yang dialami yaitu dengan self monitoring dan bome task. Setelah itu, konseli 
dibantu untuk menyadari dan mengakui bahwa dirinya telah melakukan kesalahan yaitu dengan mengkaji kembali persepsi atau pikiran-pikiran yang berkontribusi kepada lahirnya masalah berdasarkan persepsi lain atau tinjauan lain seperti dengan teknik confrontating, disputation, dan probbing. Setelah kesadaran mulai bersemi dan dorongan untuk perbaikan diri muncul (self initiating), konseli dibantu untuk menemukan serangkaian cara untuk memperbaiki kekeliruannya antara lain stopping thought, restrukturisasi kognitif, aversion and assertive training melalui role playing, dan latihan self-talk positif. (Tajiri, 2016).

Penelitian ini mengidentifikasi jati diri pesantren sebagai lembaga perbaikan ahlak pasien narkoba. Penelitian terdahulu umumnya belum menggambarkan secara operasional pendekatan konseling yang orsinil dimiliki pesantren dalam memulihkan kesadaran pasien untuk berubah dan memperbaiki ahlaknya. Perbedaannya dengan Haryanto, menekankan pada metode terapi yang dimiliki pesantren, sedangkan dengan Maesaroh terletak pada ketidakorsinilan pendekatannya dan penelitiannya menggunakan eksperimen.

Penelitian ini menggunakan metode deskriptif dalam pendekatan kualitatif, fokusnya untuk menjelaskan proses implementasi pendekatan konseling spiritual terhadap pasien baik berkait dengan proses konseling, metode konseling maupun tahapannya serta efeknya terhadap pasien.

\section{HASIL DAN PEMBAHASAN}

Pendekatan aplikasi konseling melihat suatu gejala atau peristiwa menurut sudutpandang konseling, baik itu konseling pendidikan, psikologis, spiritual maupun keagamaan. Secara sistemik pendekatan konseling akan melihat gejala mencakup pengenalan terhadap inti masalah, penentukan teknik konseling yang relevan serta aplikasi konseling dalam penanganan masalah (Curwen, Palmer \& Ruddel, 2008: 20). Tahapan itu tidak dapat dipisahkan dengan asumsi tentang terjadinya masalah dan kemungkinan pemecahan masalah yang dapat dilakukan.

\section{Asumsi Masalah pada Pasien Narkoba}

Dalam salah satu perspektif konseling (kognitif-perilaku), sebuah perilaku menyimpang erat hubungannya dengan masalah kesesatan pikiran terutama ketika dihadapkan dengan beragam permasalahan hidup, kekecewaan terhadap orang tua, kekecewaan terhadap nasib, dan ketidaktahuan memilih cara hidup yang benar. Ketidaktahuan dan kesesatan dalam berpikir atau karena faktor kebodohan membuat seseorang salah dalam menjalani langkah hidupnya. Ketika seseorang salah mengambil langkah dalam hidup maka terjadilah kesengsaraankesengsaraan.

Ini sejalan dengan pandangan Kyai Mahmud (pengasuh spiritual Pesantren Inabah VII) yang menyebutkan adanya beberapa faktor (lima hal) 
yang membuat seseorang sengsara dalam hidupnya: jahlun, ghaplah, kaslun, nafsu dan mengikuti kehendak syetan. Berdasarkan pernyataan tersebut, selain lalai (ghaplah) yang membuat hidup seseorang menjadi sengsara, adalah bodoh (jablun), tidak memiliki pengetahuan dan keterampilan, tidak pandai memanfaatkan peluang, tidak pandai menggunakan potensi yang dimilikinya, karena kenal juga tidak dengan potensinya. Faktor ketiga, kemalasan (kaslun), tidak punya keinginan, tidak punya gairah hidup untuk maju, tidak ada keinginan untuk menjadi orang yang berguna baik untuk dirinya maupun orang lain. Halhal diatas sangat boleh jadi seseorang terlampau dikuasai dan dikendalikan oleh nafsu, mengedepankan kebencian, kekecewaan dan tidak mau bekerja keras, hedonis.

Sebuah masalah munculnya karena sejumlah faktor, mengapa faktorfaktor itu begitu kuat pengaruhnya, ini karena pasien (seseorang) tidak cukup mampu menggunakan kemampuan berpikirnya secara efektif. Kekuatan pikirannya tidak cukup mampu memahami hakikat permasalahan yang sedang terjadi pada dirinya, ia pun tidak memiliki referensi pikiran yang benar dan positif tentang bagaimana seharusnya menjalani kehidupan.

Kyai Mahmud seraya mengutip pendapat Imam AlGhazali, menjelaskan ada sembilan sifat yang merusak manusia: kadzaban, selalu merusak citra, tidak punya rasa malu, selalu membuat masalah, syariq (panjang tangan), nekad, egois sok tahu sok bisa), menjual nama baik serta dhahabun, ada juga yang senangsenang, hura-hura (Mahmud, 2017). Kumpulan masalah ini saling jalin berkelindan, dan semakin kuat menjadi pengendali perilaku, terlebih apabila seseorang tidak memiliki pengetahuan yang memadai khususnya pengetahuan moral dan keagamaan yang mampu mendorong perilaku positif.

Asumsi yang terlahir berdasarkan perspektif di atas, seseorang terjerumus pada narkoba, terjadi karena kekuatan pengetahuannya lemah, cenderung hedonis, dan salah berpikir. Beragam alasan awal seseorang terjerumus narkoba, coba-coba, ikut-ikutan orang lain, diajak teman, perasaan bangga dengan kelompok, yang kemudian menjadi kebiasaan. Keterjerumusan itu dalam asumsi Kyai Mahmud mungkin saja karena bodoh, lalai dan mengikuti nafsu. Ini perlu penanganan yang mampu memantik kesadaran atas kelemahan, kelalaian yang dialaminya selama ini.

\section{Tahapan-tahapan dan Teknik Konseling}

Dalam teknik konseling terdapat beberapa tahap, yaitu, pertama, tahapan identifikasi masalah. Secara konseptual teknik identifikasi masalah dapat dilakukan dengan beragam teknik maupun cara antara lain: wawancara, analisis buku diary, isian atau angket. Pemilihan teknik sesuai dengan keadaan pasien yang ditangani. Seorang konselor hendaknya paham betul tentang karakteristik/gambaran kepribadian pasien. Berkait dengan karakteristik pasien 
dapat dikenali mulai dari pola penerimaan pasien di pesantren. Seperti dijelaskan oleh pengasuh Inabah VII, KH. Anwar Mahmud, beragam bentuk atau keadaan saat pasien datang ke inabah, ada yang datang dalam keadaan di brogol, diantar oleh aparat kepolisian, ada yang diantarkan oleh orang tuanya, dan ada pula yang datang dengan kesadaran sendiri. Dulu pernah ada pasien berinisial "J", kondisinya sangat parah, saat kedatangannya pun terpaksa dilakukan tindakan mengikatnya dengan rantai. Ternyata itu berlanjut hingga tiga tahun lamanya. Anak raja dangdut pun pernah dirantai disini seraya dinasihati, agar menerima kenyataan, bahwa rantai ini pembebas rantai api di neraka. Lebih baik dirantai saat ini daripada harus dirantai dengan api neraka. Setelah dinasihati anaknya raja dangdut itu pun menangisi dirinya.

Kondisi pasien sebagaimana di atas belum bisa dilakukan identifikasi masalah utama yang dihadapi pasien. Langkah identifikasi masalah menurut Kyai Mahmud baru dapat dilakukan setelah dilakukan perlakuan-perlakuan langkah terapis terutama mandi taubat di tengah malam yang sifatnya wajib diikuti oleh mereka. Mandi memiliki efek yang positif terhadap pengondisian psikologis pasien.

Identifikasi masalah sangat baik dilakukan di saat pasien mulai dapat koperatif. Ketika pasien tidak merasa canggung bertemu dengan pengasuh dan mulai dapat terbuka dengan pengasuh. Pertanyaan-pertanyaan untuk menggali informasi pasien antara lain berkait dengan kronologis pasien awal dapat terjerumus pada narkoba, pandangan pasien tentang perilaku menggunakan narkoba, efek yang dirasakan, serta potensi untuk keluar dari cengkraman narkoba. Berdasarkan pernyataan Kyai Mahmud, para pasien awal terjerumus karena ikut-ikutan teman, pelampiasan dari kekecewaan, terbawa arus pergaulan.

Menurut Kyai Mahmud, sering ditemukan pasien tidak mau terbuka dengan orang tua juga dengan yang lainnya tapi dengan pengasuh ternyata ia mau terbuka dan menyampaikan segala perasaan dan bahkan sesuatu yang selama ini ia tutupi. Jika dianalisis barangkali faktor personal turut berpengaruh terhadap efektivitas komunikasi. Kepribadian yang peduli, dan mampu beremfati dapat membuka pribadi tertutup seperti pasien narkoba. Konselor dengan sikap empati akan menciptakan suasana yang nyaman, terpercaya dan penuh kejujuran dalam proses konseling untuk konseli. Emfati menjadi hal yang sangat penting untuk awal mula komunikasi. Substansi dari keterampilan emfati bahwa dengan adanya sikap ini konseli akan secara terbuka menceritakan permasalahan yang dihadapi kepada konselor (Handari, 2016).

Kedua, disebut tahapan teknik. Ketika para anak bina tidak semuanya siap mengikuti proses pembinaan, bimbingan masuk untuk mengondisikan sikap mental anak bina. Bagaimana anak bina dipengaruhi pola pikirnya dari pola pikir menolak menjadi menerima, pola pikir tidak menyetujui menjadi setuju, yang 
tadinya tidak mau menjadi mau. Fungsi aktivitas bimbingan antara lain untuk memperkuat penerimaan, persetujuan dan penerimaan.

Bimbingan dan konseling pada jam-jam tertentu yaitu sehabis shalat dhuhur merupakan aktivitas layanan bimbingan untuk membangkitkan motivasi kebajikan pada diri pasien narkoba. Diantara aktivitas bernuansa bimbingan yang mampu membangkitkan motivasi untuk turut serta dalam rehabilitasi adalah pernyataan kyai ketika menasihati anak bina sebagai berikut: "Tanyakan pada dirimu ada tidak i’tikad baik pada dirimu. Kamu menjawab: punya. Lantas bisa tidak kamu mempertahankan i'tikad baik itu? Karena i'tikad baik itu motivasi diri kamu sendiri, tidak mungkin kamu bergerak tampa motivasi dan keinginan. Teruslah gali hingga hal itu betul-betul dirasakan. Bisa tidak kamu memperbaiki i'tikadmu itu?

Perilaku erat kaitannya dengan motivasi, semakin baik motivasi semakin kuat kehadiran perilaku itu. Demikian juga dengan lahirnya perilaku positif, akan sangat dipengaruhi oleh motivasi. Sekait dengan ini dalam pendekatan konseling dikenal teknik menumbuhkan motivasi atau bagaimana membangkitkan motivasi pada diri seseorang. Secara teoretik motivasi dapat dijelaskan sebagai pendorong perbuatan, berfungsi untuk mempengaruhi sikap apa yang harus seseorang lakukan, kekuatan tak terbendung yang kemudian dapat menjelma menjadi perbuatan, serta mengarahkan perbuatan sehingga seseorang dapat menyeleksi mana perbuatan yang harus dipilih dan mana yang harus diabaikan (Waluyo, 2015).

Dalam konseling spiritual dengan pendekatan kognitif-perilaku, teknik membangkitkan motivasi dapat dilakukan antara lain dengan menumbuhkan harapan-harapan dan keinginan-keinginan positif yang dapat menggantikan pikiran-pikiran yang keliru dan negatif. Diantara teknik-teknik konseling pendekatan kognitif-perilaku itu meliputi modifikasi kognitif, reframing, restrukturisasi kognitif, information giving, dapat memperbaiki pola dan tata pikir, sehingga menumbuhkan motivasi baru dalam menjalani kehidupan (Tajiri, 2016).

Cara Kyai Mahmud dalam mempengaruhi pasien menggunakan teknik motivasi dengan mengajukan pertanyaan kepada pasien, ...ada tidak i’tikad baik pada dirimu? Maukah anda memperbaiki i'tikadmu itu? Pertanyaan ini sangat mendasar dan menggugah, ..adakah i'tikad baik? Ini cukup membuat pasien mau merenungkan dirinya, ketika i'tikad itu tidak ada maka ia akan bertanya mengapa dirinya tidak punya i'tikad baik? Muncul dorongan untuk memperbaiki i'tikadnya.

Selain itu kegiatan bimbingan di Inabah VII juga diarahkan pada menumbuhkan kesadaran untuk mengakui kesalahan dan perbuatan dosa yang pernah dilakukannya. Sepanjang pasien tidak menyadari kesalahannya sulit baginya untuk dapat berubah. Upaya menumbuhkan kesadaran untuk mengakui dan menyesali kesalahan/dosa diperlukan teknik yang tepat. Cara Kyai Mahmud 
menumbuhkan kesadaran pasien dengan membangun pemahaman berbasis alquran (gaya qurani). Kyai berkata: "Lihat isyarat dalam alquran, maa gharrakum...? apa yang menyebabkan kamu terjerumus? Dengan ini diharapkan dirinya sendiri supaya mengakui sebab-sebab terjerumus pada narkoba, terus ditanya pula: sejak kapan? Dari umur berapa? Apa yang kamu makan? Apa yang Allah simpan pada diri kalian?

Falaa ta'lamu nafsun maa ubfiya lakum (engkau tidak tahu apa yang tersembunyi atau tersimpan dalam diri kalian), siapa tahu dengan potensimu itu kalian menjadi orang besar? Siapa tahu diantara kalian ada yang jadi bupati? Problemnya adalah ada yang tahu dengan potensinya ada juga yang tidak. Kebahagiaan itu milik Allah, rasul-Nya dan juga orang-orang mukmin (QS. Almunafiquun), tergantung bagaimana cara meraihnya, harus menyelaraskan dengan kehendak Allah.

Manusia itu tidak terlepas dari waktu. QS. Al-ashri: 1-4. Waktu itu berakumulasi dari jam ke jam berganti minggu kumpulan minggu menjadi bulan dan tahun. Jam tertentu kita berada di wc, jam lainnya di rumah, kadang di tempat hiburan. Pertanyaannya apakah hidup dijalani ini berkah? Kalian sekarang kaya, berada di sawah, akan melakukan panen. Secara materi akan mendapatkan padi, kalian beruntung. Tapi bagaimana hakikatnya dalam pandangan Allah, apakah kalian beruntung juga? Ternyata kalian dimasukkan neraka karena tidak bersyukur. Inilah manusia yang rugi.

Anak bina juga dibantu agar tumbuh kesadaran akan perasaan dosa. Bagaimanakah menumbuhkan kesadaran akan pengakuan salah dan dosa? Terinsfirasi oleh firman Allah "Ya ayyuhal-ladziiina amanu maa gharrakum? Punya problem apa sampai terjerumus kepada kesalahan? Apa yang menghantui hidupmu? Apakah karena orang tua cerai, dendam kepada orang tua? Suruh mereka mengakui sendiri kesalahannya. Maka mereka menjawab kami terjerumus karena a, b dan c. Mereka berterus terang. Kemudian ditanya dari usia berapa, apa yang kalian makan? Orang tua tidak tahu tapi ketika ditanya anak mengakuinya.

Bagaimana caranya? Diingatkan dengan firman Allah "falaa ta'lamu nafsun ma uhpiya lakum. Coba gali potensi kalian!’. Kemudian kembali ditanyakan kepada anak bina, "Kamu sekarang ada gak keinginan untuk maju? Menjadi orang yang bahagia?". Allah berfirman:" Kemulyaan itu milik Allah, rasul-Nya dan orang-orang yang beriman". Semua itu tergantung dengan cara apa meraihnya, harus merepresentasikan dirimu dengan kehendak Allah.

Pada kesempatan lain anak bina juga disadarkan akan faktor kegagalan yang menimpa dirinya, seraya sebelumnya diajak untuk merasakan adanya kegagalan serta faktor penyebabnya. Dengan mengacu kepada firman Allah wala tansa nasbiibaka minad dunya.... langkah nyata harus dipersiapkan. Ada kaidah 
yang berbunyi "al-ghaplatu hasaratun". Orang yang lalai siap-siaplah hidupnya akan sengsara. Bersegaralah, wa sari'uu, fastabiqul khairaat. Orang lain itu berlari masa kamu masih diam?

Dalam perspektif konseling, teknik membangun kesadaran dapat dilakukan dengan mengajak seseorang tentang hal mendasar dalam hidupnya. Teknik membangun kesadaran dapat dilakukan dengan langkah memahami SDBHSM ( $\mathrm{S}=$ Siapa saya, $\mathrm{D}=$ Darimana berasal, $\mathrm{B}=$ Berada dimana anda sekarang, $\mathrm{H}=$ Hendak kemana anda akan pergi, $\mathrm{S}=$ Sedang melakukan apa sekarang, M=Manfaat apa yang telah anda berikan?) (Rahman, 2016). Pertanyaan - pertanyaan ini menggugah kesadaran untuk mengenal potensi dirinya, membangunkan pikiran yang tertidur, dan mendorong pikiran dan perilaku baik.

Demikian juga dengan pertanyaan-pertanyaan dan pernyataanpernyataan yang diajukan kyai Mahmud kepada pasien narkoba. Apa yang membuat anda terjerumus, ada tidak keinginan untuk maju, apakah anda mau menjadi orang yang bahagia? Pikiran-pikiran semacam ini mungkin tidak pernah terlintas dalam pikirannya, ketika hal ini hadir dalam kondisi tertentu akan mampu membangkitkan kesadaran baru, menyesali perbuatan lama yang keliru, dan memunculkan keinginan baru.

Upaya pengasuh di Inabah VII juga memperjelas dan mempertegas asfek sasaran pengembangan mencakup islabul 'uqud, pasien dimotivasi agar meningkat keyakinannya; islahul mu'amalat, memperbaiki masa depannya, membuatnya menjadi mandiri, dibekali mental wirausaha. Orang yang punya potensi kemanamana tidak akan sengsara; islabul musyarokah memperbaiki lingkungan'

Ilustrasi dalam pemberian bimbingan: pembina menyampaikan pesan kepada pasiennya: besok kalian cari duit, untuk itu anda berpakaian rapi, baju celana tampak rapih, rambut rapih, pakaian pakai dasi, naik ke mobil. Kira-kira dalam pandangan kalian enak tidak? Mereka menjawab enak. Nah mengapa itu enak? Bandingkan dengan contoh kedua, anda pergi untuk mencari duit, terus mengenakan pakaian yang sobek, celana juga sobek, terus ambil cangkul. Bandingkan dengan yang pertama mau milih cara yang mana".

Anak bina juga dimotivasi dengan kisah sukses orang-orang yang pernah dibina di Inabah. Kata kyai Mahmud, ada alumnus dari sini yang kini sudah menjadi pengusaha yang sukses. Namanya Bos Jimmy, dia berbisnis di Pasar Cipulir. Kalau menurut ukuran orang itu tidak akan dapat disembuhkan. Ia dikerangkeng selama 3 tahun, kotoran diusap-usap ke sekujur tubuhnya. Kini ke toko yang dikelolanya berdatangan para pelanggan dari berbagai daerah ada yang dari Afrika, Timur Tengah. Kisah lainnya ada juga alumni yang menjadi pedagang ayam goreng. Di Tanggerang disana ada kios-kios ayam goreng Bandung. 
Ada lima hal yang membuat seseorang sengsara dalam hidupnya: jablun, ghaplah, kaslun, nafsu dan mengikuti kehendak syetan. Jadi selain lalai (ghaplah) yang membuat hidup seseorang menjadi sengsara, adalah bodoh (jablun), tidak memiliki pengetahuan dan keterampilan, tidak pandai memanfaatkan peluang, tidak pandai menggunakan potensi yang dimilikinya, karena kenal juga tidak dengan potensinya. Faktor ketiga, kemalasan (kaslun), tidak punya keinginan, tidak punya gairah hidup untuk maju, tidak ada keinginan untuk menjadi orang yang berguna baik untuk dirinya maupun orang lain. Hal-hal diatas sangat boleh jadi seseorang terlampau dikuasai dan dikendalikan oleh nafsu, mengedepankan kebencian, kekecewaan dan tidak mau bekerja keras, hedonis.

Renungkan pula firman Allah: "Telah tampak kerusakan di langit dan bumi disebabkan tangan manusia". Kata Kyai Anwar Mahmud, ayat ini dapat ditafsirkan lain, telah tempak kegagalan pada diri kalian disebabkan oleh dirimu sendiri. Coba tanya diri sendiri, kalian gagal tidak? Coba itu ulah siapa? Bapak, ibu atau orang lain? Itu karena perbuatan kalian sendiri. Kegagalan = mushibah = penyakit. Bagaimana anda merasakan pahitnya kegagalan? Apa hikmahnya, liyudiqabum bima 'amilu...supaya kamu sadar, la'allabum yarji'un supaya kalian kembali ke jalan yang benar. Wa la tansa nashibaka minad dunya (al-qashash: 77 ), ulab nyangsarakeun hidup (jangan membuat diri sengsara). Kesengsaraan itu sebagaimana telah dijelaskan, disebabkan karena bodo (jablun), lalai (ghaplab) orang lain sudah pada kemana, apalagi maraton, wa sari'u, maka bergegaslah. Alghaflah hasaratun; malas (kaslun), mengikuti kehendak nafsu (bagaimana menurut sendiri); mengikuti kehendak syetan

Kegiatan konseling yang dilakukan oleh pengasuh atau pembina di Inabah VII Sukahening Tasikmalaya merupakan kegiatan yang bersifat strategis bagi pemulihan korban narkoba. Kegiatan tersebut yang dipandang bersifat strategi merupakan langkah-langkah teknik konseling dimana fokus utama konselor tertuju pada tumbuhnya pemahaman, kesadaran dan perbaikan pada diri pasien. Kegiatan tersebut seperti:

Pertama, Stimulasi i'tikad baik, bahwa bimbingan tidak bersifat memaksa tetapi lebih merupakan ikhtiar perbantuan terbaik. Konselor dituntut kreativitas dan inovasi untuk melahirkan sejumlah cara dan pesan terbaik. Diantara kegiatan yang dimiliki Inabah VII yaitu ajakan untuk mendalami dan menghayati perjalanan sukses seseorang yang pernah mengalami masalah yang sama (terjerumus narkoba) tapi kini telah berubah total hidupnya menjadi seorang insan yang baik, sukses secara ekonomi dan diterima masyarakat. Pesan tersebut untuk menunjukkan bahwa tidak ada kata tertutup untuk perbaikan; tidak ada kata terlanjur kotor, hidup di dunia gelap tetapi jika seorang pendosa betul-betul ingin bertaubat, kembali kepada kebaikan, asal mempunyai keinginan yang kuat untuk menjadi orang baik (bertaubat) maka dia akan mampu mengubah nasib 
hidup dirinya. Sejarah pengikut nabi seperti Umar ibn Khattab, Sa'ad bin Abi Waqash adalah tokoh-tokoh penentang berat terhadap ajaran Islam, tapi dengan pemahaman yang benar mereka mampu mengubah dirinya; atau kita sering mendengar atau melihat seseorang yang nasib hidupnya seperti kecil harapan menjadi orang hebat karena kondisi orang tuanya (miskin dan kurang ilmu), tapi karena keuletan seorang anak ingin mengubah nasib keadaan dirinya, maka tidak sedikit nasib anak yang terlahir dari keluarga miskin itu ternyata di kemudian hari menjadi orang yang berhasil, bahkan mampu mengungguli orang-orang yang nasibnya sudah beruntung sejak awal.

Kedua, pemberian motivasi dan pencerahan, antara lain dilakukan dengan pembentukan pemahaman tentang arti penting mengakui keberadaan yang Maha Kuasa, mengenal Allah dengan sifat-sifatnya, bagaimana seseorang dapat merasakan kehadiran Allah dalam kehidupannya, dan sistem kehidupan manusia dan alam semesta, hakikat meyakini kehidupan akhirat, kehidupan setelah kematian serta menggapai kehidupan yang bermakna di dunia. Pencerahan dan motivasi penting diberikan karena keterjerumusan seseorang pada narkoba menunjukkan gelapnya hati, rendahnya pemahaman dan penghayatan nilai keagamaan. Melalui kajian agama secara baik dan benar , bimbingan agama mengantarkan korban narkoba memiliki hati dan pikiran yang tercerahkan.

Ketiga, kesiapan pengasuh untuk menjadi pelindung, pembimbing dan pendamping. Kehadiran sosok seseorang yang dipercaya dan tidak disegani, dipercaya sebagai orang yang peduli dan berempati, membuat pasien/korban narkoba luluh jiwanya untuk mengikuti aturan main yang berlaku di tempat pembinaan. Kondisi ini memungkinkan terbimbing bukan saja siap menerima wejangan akan tetapi juga tak sungkan mereka menyampaikan keluhannya kepada pengasuh tentang apa yang dialaminya, dan kronologis keterjerumusannya pada narkoba, suatu kondisi dimana kepada orangtuanya sekalipun sebelumnya tidak pernah mau terbuka.

Keempat, konselor mengupayakan melalui pemilihan waktu dan suasana yang tepat. Tampaknya tidak semua manusia dengan begitu saja berkesiapan diri menerima nasihat atau wejangan, alih-alih menerima malah berbalik dengan amarah. Inilah pentingnya mencari waktu dan suasana yang tepat dalam menyampaikan pesan atau nasihat. Seperti yang terjadi di Inabah VII, menurut pengasuh di Inabah VII memberikan wejangan itu harus mempertimbangkan suasana hatinya, adakalanya kami menasihati mereka saat mereka menonton televisi, saat termenung sendiri, saat lenggang dalam suasana tatap muka. Khususnya yang bersifat pribadi sangat memungkinkan dengan tatap muka, ada juga dalam suasana kelompok dengan sedikit berkelakar tampa harus menyinggung dan merendahkan. Misalnya memancing tanggapan atas sesuatu peristiwa seandainya kecelakaan yang menimpa seseorang hingga meninggal 
dunia terjadi pada kita dan itu gara-gara narkoba apa komentar anda? Dalam suasana kelompok mereka saling menunjuk, dan mereka memperlihatkan keengganan untuk mengalami nasib serupa dengan yang diibaratkan.

Ketika pendekatan konseling yang betul-betul diterapkan maka inilah yang terjadi pada terbimbing/konseli antara lain ada penerimaan diri, kepasrahan dan ketulusan menjalani program pembinaan di pesantren, secara jentelmen mau mengakui kalau apa yang pernah dilakukan sebagai salah dan dosa, diikuti oleh dorongan atau keinginan untuk bertaubat dan memperbaiki diri; selain itu juga terbangun rasa kepercayaan diri dan kesiapan kembali menjalani kehidupan di masyarakat secara sehat.

\section{Efek Pendekatan Konseling terhadap Pasien Narkoba}

Keberadaan pendekatan konseling bersifat menguatkan dan mengokohkan implementasi langkah-langkah terapi yang dijalankan pasien. Ketika pasien mampu mengikuti rangkaian dengan sempurna dan mampu menjiwainya, maka implikasinya terhadap proses kesembuhan atau kepulihan pasien narkoba. Dengan kesungguh-sungguhan pasien mengikuti rangkaian terapi telah banyak pasien narkoba yang berhasil disembuhkan, bahkan ada peneliti yang menyebut derajat kesembuhan itu hampir mencapai sembilan puluh persen berhasil.

Signifikansi bimbingan dan konseling mencakup dua keadaan: pertama, tercerahkannya pola pikir pasien tentang pilihan perilaku yang harus diambil, meninggalkan pola pikir lama yang merusak dan mengambil pola pikir baru yang positif dan konstruktif, menyadari akan kesalahan dan kekeliruan pandangan dan kebiasaan selama ini, munculnya keinginan yang kuat untuk bangkit dengan kehidupan yang baru. Sedangkan yang kedua, kondisi jasmaninya yang semakin membaik, tidak lagi terkungkung oleh rasa ketergantungan oleh obat.

Diantara teori konseling ada yang menekankan pentingnya kognitif untuk mengendalikan perilaku (kognitif-perilaku). Teori tersebut berbunyi bahwa variabel kognitif, emosi dan perilaku saling berhubungan secara fungsional. Tritmen bertujuan untuk mengidentifikasi dan memodifikasi prosesproses berpikir maladaptif dan perilaku-perilaku problematik konseli melalui restrukturisasi kognitif dan teknik-teknik perilaku untuk mencapai perubahan, Disebut juga modifikasi perilaku kognitif, cognitive behavioral therapy (VandenBos, 2007: 188). Pendekatan kognitif-perilaku memiliki asumsi bahwa problem perilaku bersumber pada pikiran-pikiran yang salah (error think), keyakinan yang keliru ('irrational belief) yang kemudian berpengaruh terhadap sikap, cara merasa, 
H. Tajiri

cara berpikir dan cara bertindak/berperilaku (Spiegler \& Guevremont,2003 $: 310)$.

Berdasarkan teori tersebut jika pasien masih terkungkung oleh pola pikirnya yang salah tentang kebiasaan mengkonsumsi narkoba, maka sulit baginya untuk secara tulus mengikuti segala ketentuan yang diberlakukan. Pasien diajak komunikasi oleh pembina/pembimbing dengan memanfaatkan suasana yang tepat untuk berkomunikasi seperti komunikasi individual saat menonton televisi, atau secara kelompok dalam waktu-waktu layanan bimbingan secara terjadwal.

Dalam konsep inabah intinya kembali memanusiakan manusia. Kondisi manusia yang sudah terlibat kejahatan seperti pecandu narkoba sedang rusak. Kerusakan itu mulai hati, pikiran, sampai kepada fisiknya. Hati yang seharusnya menerima yang benar itu baik justru sebaliknya. Yang benar dianggap tidak baik atau sebaliknya. Begitu pula pikiran yang seharusnya menerima logika yang benar, tidak berfungsi. Demikian halnya dengan anggota badan atau fisik, sudah tidak peka lagi. Telinga yang seharusnya menerima dengan baik alunan musik yang merdu malah terasa gelisah. Nah, ketika tiga titik itu sudah rusak, seseorang perlu dibenahi. Penanganannya dimulai dengan do'a sebelum mandi, kemudian mandi tobat dan tahajud. Kemudian ada dzikir dengan membaca kalimah syahadat sebanyak 150 kali. Bacaan dzikir diucapkan dengan nada yang keras mengentak. Kemudian diikuti gerakan kepala menyesuaikan irama bacaan. Kenapa dibaca dengan nada keras dan mengentak? Karena untuk menghancurkan hati yang sudah membatu (Abidin).

Menurut Kyai Anwar Mahmud dalam bimbingan yang berlangsung disampaikan kepada mereka tentang pentingnya memahami jenis-jenis obat yang selama ini mereka konsumsi, dijelaskan segi bahaya dari obat tersebut dan status hukumnya dalam ajaran agama. Bahaya narkoba tersebut baik terhadap sistem syaraf, menyebabkan kecanduan, menguras biaya yang tinggi, dan mematikan hati. Gara-gara narkoba seseorang menjadi tidak terarah tujuan hidupnya (disorientation). Gara-gara narkoba banyak orang meninggal dunia, terutama saat mengendalikan kendaraan sambil mengkonsumsi narkoba pandangan menjadi tidak fokus, akibatnya terjadilah kecelakaan.

Saat anak bina dimandikan, sang pembina sambil mengucurkan air di atas kepala anak bina tak luput sambil dido'akan dan hikmah mandi untuk membebaskan penyakit yang diderita dan juga ketergantungan terhadap narkoba. Efek psikologis yang dirasakan anak bina berupa sentuhan kasih sayang yang ia 
rasakan, merasa terbantu penghilangan berbagai kotoran baik jasmani maupun ruhani. Ini sejalan dengan sebuah atsar dari Abu Na'im yang berbunyi: "Barangsiapa yang membasuh dua telapak kakinya dengan air dingin maka ia terbebas dari sakit di kepala". Dari hadits ini kyai pesantren mengembangkan pemahamannya menjadi mandi malam dengan air dingin, dengan ini orang akan terbebas dari sakit di kepala dan dari ketergantungan terhadap narkoba.

Selain menggunakan dalil di atas, juga beberapa ayat al-Qur'an menjadi hujjah ritual mandi ini, antara lain: "Ingatlah ketika Allah membuat kamu mengantuk untuk memberi ketentraman dari-Nya, dan Allab menurunkan air bujan dari langit kepadamu untuk menyucikan kamu dengan bujan itu dan menghilangkan gangguangangguan setan darimu dan untuk. menguatkan hatimu serta memperteguh telapak kakimu (QS. Al-Anfal: 11)". "Dan ingatlah akan hamba Kami Ayyub ketika dia menyeru Tuhannya, "Sesungguhnya aku diganggu setan dengan penderitaan dan bencana. Allah berfirman,"Hentakeanlah kakimu; inilah air yang sejuk untuk mandi dan untuk minum. Menurut Jalalin, ketika Ayyub diperintabkan menghentakean kaki, maka ia hentakean kaki dan menghantamkannya, setelah itu tiba-tiba mengalirlah mata air dari bekas bentakean kakinya. Kemudian dikatakan pula kepadanya,"Mandilah kamu dengan air ini yang dingin dan minumlah kamu daripadanya." "Segeralah Nabi Ayyub mandi dan minum dan bilanglah semua penyakit yang ada di dalam dan di luar tububnya". (QS. Shad: 41-42 ). Alasan-alasan ini akan mampu meningkatkan keyakinan dan harapan pasien bahwa dirinya dapat sembuh dari penyakitnya.

Selain itu dari sisi keberhasilan, setidaknya ada dua indikasi keberhasilan dalam mengikuti proses terapi yaitu saat menjalani proses dengan baik dan pada dinamika kejiwaan pasien berupa tumbuhnya semangat dan gairah baru dalam menjalani kehidupan. Ini sejalan dengan pandangan Westbrooks tentang cara mengevaluasi keberhasilan konseling. Menurut Westbrook sekurang-kurangnya ada dua aspek yang dievaluasi yaitu pada proses dan pada hasil atau perubahanperubahan yang terjadi pada konseli. Seberapa akurat konseling dikembangkan terhadap target masalah, penggunaan pengukuran yang relevan pada awal dan akhir konseling (Westbrook, 2007: 249).

Keberhasilan dalam menjalani proses maksudnya penerimaan diri, kesiapan diri, ketulusan untuk mengikuti rangakaian terapi seperti bangun di tengah malam untuk melakukan mandi taubat secara rutin setiap malam, melakukan shalat-shalat baik shalat fardhu maupun shalat sunat secara 
H. Tajiri

berjama'ah. Selain itu bersiap diri dengan ketulusan menjalankan dzikir bersama dipandu oleh pembina.

Sedangkan dari segi dinamika perilaku, seperti tampak dari beberapa testimoni salah satunya pasien bina bernama A (17 tahun), seorang remaja asal Palembang yang saat ini tengah menjalani proses rehabilitasi di Pesantren Suryalaya Inabah VII, sudah sebulan ia menjalani rehabilitasi, dan kini mengaku sudah bebas dari pengaruh narkoba. Menurut pengakuannya kronologis dirinya terjerumus pada narkoba, "Pertamanya sih ganja sekitar tahun 2012 waktu umur 14 tahun sampai sekitar dua tahun-an. Selain ganja pakai sabu juga baru sekitar setahun setengah,". Awalnya kenal narkoba (narkotika dan obat-obatan berbahaya) dari seorang teman yang bekerja untuk polisi. Ia mulai kecanduan sampai akhirnya ada tetangga yang mengetahui hal tersebut dan melaporkannya ke orang tua yang kemudian mengantarkan dirinya dan membawanya ke pesantren suryalaya. Di dalam pesantren, A mengaku mendapat berbagai hal namun yang paling pokok adalah pelatihan mental lewat siraman rohani. Disini saya mendapatkan pelajaran zikir, tata cara sholat, berperilaku baik, dan pengalaman cerita dengan teman-teman yang lain. Enggak berat, enak malah pikiran jadi tenang.

Rehabilitasi yang penuh dengan kegiatan rohani dikatakan oleh A membuat dirinya menjadi tidak kosong pikiran dan menjadi sakaw. Hanya saja memang ia akui terkadang dirinya merasa bosan karena kegiatan yang monoton. "Enggak, enggak sakaw. Paling ya jenuh saja tapi gak nge-blank," imbuhnya. Pembina dari Pesantren Suryalaya Inabah VII, Anwar Mahmud, mengatakan anak seperti A yang terlihat memiliki kemajuan yang baik bukan tidak mungkin akan dibantu untuk melanjutkan sekolahnya.

Dinamika perilaku juga terjadi pada Atok (nama samaran), remaja berumur 24 tahun ini berasal dari Pontianak, sempat menjalani hukuman selama satu tahun di kampung halamannya. Dirinya merupakan pemakai aktif sabusabu, rata-rata sehari mengisap 0,5 gram. Awalnya dikasih Cuma-Cuma namun setelah itu disuruh membeli Rp. 800.000/gram. Ia sempat sering sakaw ketika awal-awal tinggal di inabah VII. Pada pekan pertama, sempat beberapa kali sakaw, namun bukan kejang-kejang atau teriak-teriak. Sakaw-nya itu malas saja, malas makan, dan malas lainnya. Setiap kali sakaw, maka ia dimandikan oleh pembina saat dini hari. Setelah itu diajak shalat malam. Kemudian berzikir sampai disambung shalat shubuh. Setelah sebulan lebih di inabah Atok tidak kecanduan lagi terhadap narkoba. 
Perubahan-perubahan yang terjadi pada pasien narkoba sejalan dengan penelitian Moh. Toriqul Chaer (2014) dalam artikelnya berjudul Terapi Inabah dan Pecandu, menurutnya korban narkoba mendapatkan ketenangan dan keyakinan diri selama mengikuti terapi inabah.

Secara menyeluruh proses konseling spiritual terhadap penyembuhan pasien narkoba di Inabah VII dapat digambarkan sebagai:

Tabel Skema Konseling

Pembimbing/Konselor:

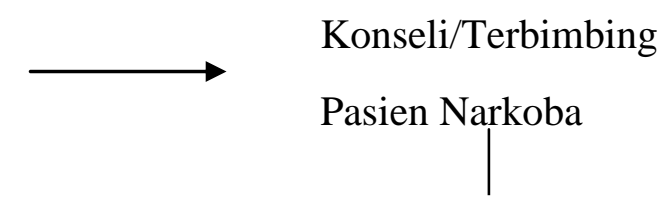

- Stimulasi i’tikad baik

- Pengungkapan atas

- Kesiapan menerima keluhan pasien dasar kemauan

- Motivasi dan Penyadaran

- Pencerahan dan bimbingan perilaku

- Pemantauan

- Waktu dan situasi yang tepat sendiri

- Pengakuan atas kesalahan atau dosa

- Keinginan bertaubat dan memperbaiki diri

- Kepercayaan diri dan kesiapan kembali menjalani kehidupan di masyarakat secara sehat 


\section{PENUTUP}

Pendekatan konseling dapat dilakukan secara integratif dengan beragam pendekatan lain (termasuk kognitif-perilaku dan spiiritual) dalam penanganan masalah-masalah yang dihadapi manusia baik masalah pribadi maupun sosial. Dalam pembahasan ini bimbingan dan konseling terintegrasi dalam terapi spiritual terhadap masalah sosial korban penyalahgunaan narkoba. Bimbingan dan konseling memberikan daya dukung terhadap mutu proses dan pencapaian tujuan terapi spiritual yang dilaksanakan. Beberapa kendala yang terjadi karena kemalasan atau keengganan pasien mengikuti kegiatan terapi ditangani dengan konseling. Bimbingan dan konseling juga memberikan penguatan motivasi pasien dalam menjalani proses terapi, memberikan pemahaman tentang hakikat terapi yang sedang diikuti serta bahaya narkoba yang harus segera dijauhi. Selain itu bimbingan dan konseling memberikan pencerahan atas orientasi hidup yang lurus dan benar, membangun kepercayaan diri dan keyakinan diri saat mereka harus kembali hidup di masyarakat.

Bimbingan dan konseling yang dipraktikan di Inabah VII antara lain memberikan bimbingan dalam jadwal-jadwal yang sudah ditentukan seperti sehabis shalat dluhur setelah makan siang, secara individual maupun kelompok serta pada saat santai saat menonton televisi. Usaha yang ditempuh pembina antara lain membangun kesadaran pasien agar mengenali kegagalan, kekeliruan, kesalahan. Setelah itu pasien mengakui kekeliruan dan kesalahan yang pernah dilakukannya. Ketika pasien telah mengakui kesalahan yang pernah dilakukannya, pembina bersama-sama dengan pasien mencari tahu apa faktor-faktor yang menyebabkan dia terjerumus melakukan kesalahan. Setelah itu pembina membantu pasien mengembangkan i'tikad baik yang seharusnya dimiliki, dengan teknik tertentu agar i'tikad itu betul-betul tumbuh dalam diri pasien. Pembina juga mengembangkan pemahaman pasien tentang sejumlah faktor yang dapat membuat seseorang gagal dan mengalami kesengsaraan dalam hiidupnya. Kemudian dijelaskan dengan terapi yang diikuti dengan baik seperti mandi malam, tahajjud, zikir, shalat dan membaca al-Qur'an sedikit demi sedikit keinginan untuk menjadi normal akhirnya dapat dicapai.

Signifikansi bimbingan dan konseling terhadap proses terapi, bahwa bimbingan dan konseling mampu memberikan penguatan keinginan, 
meningkatkan keshabaran, serta optimisme. Kehadiran sosok pembina yang berjiwa pembimbing/konselor membuat pasien merasa nyaman, ada yang mendampingi, ada yang memperhatikan, ada yang peduli terhadap nasibnya. Hal tersebut karena seorang pembina selalu siap membantu dan memberikan bimbingan, menjadi parner curhat dan tempat bertanya. Pembimbingan dengan sejumlah wawasan dan kedalaman pengetahuan khususnya dalam bidang agama dan sosial dapat memperbaiki kualitas pasien dalam berpikir, serta kualitas dalam merasa, mengenal pikiran-pikiran dan perasaan-perasaan yang keliru selama ini dan upaya memperbaikinya dengan petunjuk jalan hidup yang benar.

\section{DAFTAR PUSTAKA}

Aqib, K. (2005). Inabah Jalan Kembali dari Narkoba, Stres dan Kehampaan Jiwa. Surabaya: PT. Bina Ilmu.

Chae, M.T. (2014). Terapi Inabah dan Pecandu. Jurnal Al-Murobi , I ( 1), 60 $-76$.

Handari, S. (2016). Emfati sebagai Pengembangan Seni Konseling untuk Efektivitas Pelayanan Konseling. Lentera, XVIII (1), 49-64.

Haryanto, S. (1999). Terapi Religius Korban Penyalahgunaan Nafza di Inabah PP. Suryalaya. Buletin Psikologi, VII (1), 35 - 57

Lestari, P. (2012). Metode Terapi dan Rehabilitasi Korban Nafza di Pondok Pesantren Suryalaya Tasikmalaya. Dimensia, VI ( 1), 1 - 16

Rahman, I.K. (2017). Gestalt Profetik (G-PRO) Best Practice Pendekatan Bimbingan Konseling Sufistik. Jurnal Religi, VIII (1), 151-172.

Spiegler, M.D. \& Guevremont, D.G. (2003). Contemporary Behavior Therapy. Fourth Edition. USA: Thompson.

Tajiri, H. (2016). Kendali Diri Perilaku Seksual dan Pengembangannya melalui Konseling pada Madrasah Aliyah di Kabupaten Bandung. Jurnal Cendekia, XIV (1), 91-106.

Waluyo, Y.T. (2015). Peran Tutor dan Meningkatkan Motivasi Belajar Peserta Didik melalui Pendekatan Andragogi di Rutan Banjarnegara. NFECE, IV (1), 71-78.

Vandenbos, G.R. (2007). Dictionary of Psychology. Washington DC: American Psychological Association. 
H. Tajiri

Westbrook, D. (2007). An Introduction to Cognitive Behavior Therapy, Skill and Aplication. Los Angeles: Sage Publication. 